\title{
A ORGANIZAÇÃO COMO RELIGIÃO LAICA
}

Se comparamos a vida hoje com 50, 60 anos atrás, é inegável constatar que as pessoas estão cada vez mais dependentes das organizações. As organizações estão presentes de forma absoluta em nosso dia a dia, de tal sorte que podemos até afirmar que elas funcionam como elemento mediador entre as pessoas e a realidade.

A área de estudos organizacionais é extremamente multifacetada, tendo recebido influências marcantes das mais diversas perspectivas epistemológicas, desde a sociologia funcionalista até a fenomenologia e, mais recentemente, o pós-estruturalismo (Burrell \& Morgan, 1979; Reed, 1999). A despeito da marcante heterogeneidade das matrizes epistemológicas do campo, se analisarmos os principais livros anglo-saxões que revisam a área, percebemos que os estudos com base em Freud, bem como as diferentes perspectivas psicanalíticas, ainda encontram pouco apelo entre os teóricos organizacionais. Por exemplo, o clássico Burrell \& Morgan (1979), ao apresentar os seus famosos 4 paradigmas da teoria organizacional, faz pouquíssimas menções à Freud e nenhuma aos demais teóricos psicanalíticos. Clegg, Hardy e Nord (1999), em seu amplamente divulgado Handbook, não apresentam nenhuma leitura psicanalítica das organizações. Hatch (1997), ao apresentar as diversas temáticas da teoria das organizações, também não faz qualquer menção à psicanálise.

Entretanto, se nos voltamos à tradição de língua francesa de estudos organizacionais, percebemos que este quadro é bastante diferente. A perspectiva psicanalítica tem sido difundida de forma mais sistemática e encontra grande apelo entre os teóricos organizacionais nesta tradição (De Gaulejack; Enriquez e outros).

Tradicionalmente, os estudos organizacionais brasileiros têm sofrido forte influência das matrizes teóricas anglo-saxãs (Bertero \& Keinert, 1994 ;Vergara, 2000) e a utilização das idéias de Freud, muito embora encontrem alguma ressonância (Prestes Motta \& Freitas, 2000; Chanlat, 1994), têm sido ainda muito restrita. 
Dentro deste quadro, o objetivo deste artigo é tentar realizar uma leitura das organizações com base em leituras psicanalíticas realizadas por autores de análise organizacional com o intuito de apontar para como a dinâmica das organizações contemporâneas pode ser encarada como uma forma de religião laica. Assim, o artigo pretende contribuir para o desenvolvimento de uma leitura psicalítica das organizações na área de estudos organizacionais. Para tanto, na primeira parte discutimos a cultura, o fascínio e a sedução nas organizações, posteriormente, apontamos os aspectos fundamentais das organizações hipermodernas e analisamos como esses aspectos se articulam gerando a organização como religião laica

\section{Cultura, Fascínio e Sedução nas Organizações}

"O Futuro de uma Ilusão" é um livro em que Freud se dedica ao estudo da sociedade, no qual é desenvolvida uma reflexão sobre a natureza da civilização e de suas ilusões expressas em idéias religiosas. O livro esboça uma teoria da cultura e da história e concede um novo lugar à idéia ou noção de ilusão. $\mathrm{O}$ processo civilizatório depende das ilusões da civilização utilizadas para manter sua coesão, bem como as suposições que determinam as regulamentações políticas. Por traz da crença, da psicologia coletiva e individual, está a ilusão. Por traz das organizações estão as ilusões, como podemos facilmente deduzir.

Freud parte do conceito de cultura, como sendo tudo aquilo que está acima da condição animal. Não vê diferença significativa entre cultura e civilização. Cultura é todo o saber e todo o poder voltados para o domínio das forças da natureza, dirigidos à satisfação das necessidades humanas, assim como as organizações necessárias para regular essa aquisição. Todas as organizações fazem parte da cultura, ou, dito de outra forma, todas as organizações são cultura.

A cultura impõe interdições no nível coletivo, da mesma forma que o superego no nível individual. Assim, em um certo sentido, a cultura é análoga ao superego. É por esta razão que num dado momento, Freud chama a cultura de superego coletivo. A cultura assume sua função primária quando impõe interdições ao assassinato, ao canibalismo e ao 
incesto. As pessoas, porém, deixam de cometer assassinato ou incesto, para se entregarem à avareza, à agressividade, ao sexo desmedido, à mentira, à fraude, à calúnia e à corrupção. As interdições desempenham um papel importante na manutenção da cultura. Todavia, nem só de interdições vive a cultura. Ela também se mantém mediante satisfações de ordem narcísica experimentadas pelas pessoas quando participam dos seus ideais e criações. Frases proferidas com orgulho, como eu sou da McKinsey, trabalho da DPZ, sou professor da USP, deixam transparecer satisfações desse tipo.

O objetivo dessas satisfações é promover a reconciliação dos homens com as pulsões por ele sacrificadas. Entretanto, isto não é suficiente para impedir que haja muitos homens e mulheres hostis à cultura. Para eles não há nenhuma identificação possível, salvo na contra cultura.

Dito de forma simples, a cultura é um corpo de interdções, que tem por objetivo defender-nos dos rigores da natureza, tais como as doenças, o destino, inclusive a morte, a relação predatória e a fraqueza humana (Enriquez, Eugène, 1990, pg.84).

Segundo a psicanálise, o homem aspira a ser protegido e controlado. A cultura desempenha essa função, já que o estado natural é difícil de suportar devido a falta de proteção e controle. A religião, enquanto sistema de idéias, é parte importante da cultura, pois faz com que a natureza morra em nós. Daí a tríplice missão dos deuses gregos: exorcizar os temores da natureza, reconciliar os homens com a crueldade do destino, a morte, e compensá-los pelos sofrimentos e privações.

A religião visa proteger o ser humano da ansiedade, do desamparo infantil que sempre está se manifestando. Na verdade, a mãe é a primeira proteção contra a ansiedade. Já o pai, aparece como o mais sólido baluarte contra os poderes da natureza. A religião faz nascer deuses que serão a duplicação das figuras paternas. Esses deuses provocam duplicadamente temor e admiração. Todos querem um pai, querem ser protegidos contra a debilidade humana.

A religião intervém para fornecer uma origem divina às prescrições culturais. Fornece instâncias benevolentes e protetoras. Nostálgicos dos pais, homens e mulheres criam deuses à sua imagem. No livro "Totem e Tabu", Freud vê a religião surgindo do 
sentimento de culpa. Mais tarde, em "O Futuro de uma Ilusão", a religião surge do desamparo humano.

As idéias religiosas são ilusões, na medida em que não podem ser confrontadas com a realidade. Todas as ilusões derivam de desejos humanos. De fato, as idéias religiosas correspondem aos desejos mais fortes e antigos da humanidade.

Descartes, em sua "Primeira Meditação" procurou identificar a ilusão com a figura do gênio maligno enganador. Para o filósofo, a ilusão é a falsa opinião, um erro. Trata-se de uma posição racionalista que opõe a ilusão à verdade.

No pensamento de Freud, a ilusão não é igual a um erro. Ela é indiferente à realidade e também à efetividade. Sendo mais preciso, a ilusão é uma crença cuja realização de um desejo constitui fator proeminente em sua motivação. Há um desprezo nas relações com a realidade e a efetividade.

É crença, porque origina-se no amor, fazendo desaparecer o prazer ligado ao trabalho do pensamento. A ilusão funda-se sobre a crença na possibilidade de realização do desejo. O desejo torna-se instância acima da razão.

Afirmamos que a ilusão é indiferente à realidade ou à efetividade. De fato, não poderia ser diferente, já que a realidade poderia desmentir o objeto da crença.

A ilusão possui as seguintes características: a crença, ser motivada pelo desejo e a indiferença à realidade. A mais inexplicável das ilusões é a religiosa. É a única que se funda sobre o amor por um objeto ausente e invisível, cuja luminosidade não pode ser jamais embaçada.

Descobrimos os crimes de Stalin, Hitler e Mao, mas ninguém descobriu os "crimes de Deus". O mais idealizado dos objetos sexuais, acaba se cobrindo de rugas e mostrando suas imperfeições, mas o objeto com o qual existe uma união mística mantém-se sempre igual. É um objeto que existe fora de qualquer razão.

Existirão meios de combater as ilusões. Entendem alguns que para expulsar a religião da civilização ocidental será preciso fazê-lo pela sua substituição por outro sistema 
de doutrinas, que logo assumirá todas as características psicológicas da religião: a mesma "santidade", a mesma rigidez, a mesma intolerância e a mesma proibição do pensamento.

É importante não esquecer que as necessidades humanas são uma parte da realidade. Portanto, nunca supriremos dos homens a tendência à satisfação de seus desejos, bem como sua necessidade de proteção. Freud, em parte, pensa dessa forma e isto o angustia.

Constituindo ilusões, as idéias religiosas, são indiferentes à efetividade e à realidade e essas, a todo momento, podem desmenti-las. É da natureza da religião impedir o caos e exercer um rigoroso controle social mediante normas, regras e hierarquias. Tais mecanismos estabelecem estruturas rígidas, intolerância e proibição do pensamento. Baseia-se na sacralização de um objeto, utilizando-se da necessidade de proteção do homem. É enquanto controle e regulação que as interdições sociais são sacralizadas, adquirindo mais força. Este controle só poderá tornar-se menor com o surgimento de outras forças, possuidoras de características similares, tais como as organizações.

Como a religião, as organizações são formas de controle social, exercido através de mecanismos que criam uma rigidez que age como barreira aos comportamentos espontâneos e instintuais. Também estabelecem direitos e deveres, que atuam como uma forma de traduzir a intolerância. Da mesma forma que a religião, elas restringem o pensamento, através de manuais de procedimento e das hierarquias, já que estes pressupõem o nivelamento do pensar, tendendo à sua paralisia. Por fim, as organizações sacralizam as chefias, as missões e suas imagens. A carreira também pode ser sacralizada e em alguns casos ganhar autonomia com relação à organização. Uma carreira de executivo bem sucedido pode tomar o ideal do ego, tanto quanto uma organização, cumprindo uma e outra uma função de aprisionamento psíquico, assumindo ambas as características de uma religião.

Do ponto de vista macrosocial, organizações e carreiras são formas alternativas à religião propriamente dita, podendo, em certo sentido, substituí-la, como objeto idealizado de satisfação dos desejos do indivíduo, bem como mecanismos de controle social. Todavia, as organizações não podem substituir a religião, no que se refere à imagem de deus. Esta 
não muda, nem se desmoraliza. A relação dos indivíduos com as organizações é menos perene, precisando sempre ser alimentada; a relação com Deus é mística, total.

A relação amorosa não pode ser tão forte no caso das organizaçães, mas pode ser bastante intensa, no caso de saberem "sacralizar" devidamente objetos e interdições. A religião existe acima de qualquer razão. Por esta razão sua perenidade está garantida, bem mais do que qualquer outro tipo de ilusão, incluindo as carreiras e as organizações. A religião é inexplicável e incontestável, por definição; já as carreiras e organizações podem ser contestadas, revistas, extintas e recriadas. Organizações e carreiras podem transformarse em religiões laicas, desde que usem ferramentas semelhantes às utilizadas pela religião, estabelecendo e mantendo uma relação amorosa e quase mística com os seus funcionários. ( Schikmann,R.; Coimbra, R. e de Battisti, P., 2000).

A carreira de um indivíduo pode ser objeto de amor e fonte de aprisionamento, tanto quando se trata de carreira interna à organização, cujo galgar significa a posse do amor da organização, quanto quando se trata de carreira interorganizações, compreendendo um jogo mais complexo de símbolos de status, no qual as organizações funcionam como degraus, cuja subida significa o amor que aqui se reveste mais claramente de aprovação social.

Essencial ao estudo da organização, é a compreensão do vínculo social sobretudo como psicológico. No texto "Moisés e o Monoteísmo", expandindo o que já fora tratado em "Totem e Tabu", Freud desenvolve este conceito, colocando em seu centro a figura aglutinadora e criadora de amálgama do "grande homem". Nunca foi merecedora de grande atenção esta figura, que também pode ser chamada de líder ou herói, nos textos de sociologia. Em "Moisés e o Monoteísmo", Freud reconhece Moisés, guia do povo judeu, como "grande homem".

Moisés é o príncipe do Egito, que buscando seguidores para a seita do deus Aton, interessa-se por um povo escravo, os judeus, e o transforma em povo eleito por Deus, assumindo a tarefa de levá-lo à terra prometida. Há povos que escolhem deuses, mas a escolha dos judeus é o único caso de Deus escolhendo um povo. Os judeus entram na terra prometida, mas Moisés, já velho, morre sem poder fazê-lo. 
Para que a relação entre o guia e os guiados pudesse acontecer nas condições históricas e lendárias, alguns vínculos se estabelecem. O líder seduz o povo, que o introjeta, uma vez que ele está num lugar de identificação e referência, de onde há adesão. O povo que adere é o que introjeta. Fica clara a necessidade da figura do pai, descrita com cuidado em "Totem e Tabu", bem como a importância que pode ocupar no lugar do ideal do ego, como Freud mostra no livro "Psicologia das Massas e Análise do Ego".

Formação intra-psiquíca relativamente autônoma, o ideal do ego serve de referência para o ego. Ele se desenvolve como instância de referência, auto-observação e censura. Freud vê ali uma formação separada do ego, que torna possível a explicação da fascinação amorosa e a submissão a um líder, quando este é colocado pelo indivíduo no lugar do seu ideal do ego.

Utilizando mecanismos de sedução, o líder gera fascínio. Os liderados, acabam assumindo suas feições. É o líder-herói que dá à massa a sua identidade e suas feições, trazendo a auto-estima, e sua referência. É a figura do pai.

Nas organizações, os líderes trazem a simbologia, o conjunto de elementos que fazem com que os grupos, ou o conjunto da organização, o sigam, amem, imitem ou odeiem. Esse conjunto de referências possibilita a existência de grupos de organizações e povos. O pai-líder cerceia a pulsão e em troca protege contra os rigores da natureza e do destino, da morte. Ele é fornecedor do status, dos grandes símbolos que escravizam muitos às organizações. São nomes ou sobrenomes aos quais as pessoas se submetem por alguma segurança.

Se as organizações e carreiras podem assumir o lugar do ideal do ego, quando a referência é difusa, do tipo materno, com muita segurança em troca de muita cobrança; líderes podem ser colocados no lugar do ideal do ego, em organizações mais tradicionais, centradas na hierarquia e em um modelo paterno.

O ideal coletivo surge do encontro ou convergência dos ideais dos egos dos indivíduos, isto é, os indivíduos colocam um só e mesmo objeto no lugar dos seus ideais dos egos. Conseqüentemente, identificam-se uns com os outros. Este é um mecanismo amplamente utilizado pelas organizações como um meio de alinhamento de todos. Na 
verdade, todo o seu marketing é feito a partir do mesmo fenômeno. A maioria das pessoas se submete. A maioria é induzida a um consumo que lhe permite a ilusão de proteção, segurança e status. Certas roupas, carros, residências, colégios, empresas são, com tudo o mais, associados a esta ilusão. Tudo isto confere identidade e possibilita ao indivíduo, que introjetou esses símbolos, aderir a seu grupo de referência. Trata-se de uma relação cujas palavras fundamentais são dominação, submissão, autoridade, fascínio, ódio, sedução, sedutor e seduzido.

Quando o modelo de referência é trazido pelo líder e sua organização, temos um modelo paterno, um "dever ser" ou censura que determina o modo de operação que todos obedecem. Há na relação ego/ideal do ego, uma dimensão de medo do castigo, e submissão por amor. $\mathrm{O}$ ideal e a interdição andam juntos. $\mathrm{O}$ superego corresponde à autoridade e o ideal do ego ao modo como se deve comportar para que haja correspondência à expectativa da autoridade.

Podemos prosseguir, tomando dois exemplos de organizações, milenares e monosexuais, aparentemente visando a estabilidade. São a Igreja e o exército, duas instituições extremamente antigas de nossa civilização que dão corpo para o ideal do ego de seus membros. Se no exército existe o comandante e as regras de igualdade, na Igreja existe a crença em Deus, que une a todos. Nos dois exemplos a figura do pai, grande homem ou líder, é uma referência presente. Num, há o líder corporificado no comandante, noutro existe a divindade que é perfeita e invisível. Freud sustenta que para os judeus, há Deus e Moisés, o guia, juntos. Trata-se da figura paterna duplamente representada.

A figura do líder, nas organizações, sintoniza-se com o conteúdo símbólico organizacional. O líder é visto como aquele que levará todos ao futuro. Esse é o conteúdo presente em toda a literatura corrente sobre o papel do líder. Um exemplo que endossa essas observações: em uma empresa dá-se a demissão de seu diretor-presidente, um reconhecido líder. Num primeiro momento sente-se o choque compartilhado e ouve-se um discurso de órfãos, que jamais dizem uns aos outros que o líder foi demitido. Em seguida, surge um novo discurso: este líder nos trouxe até aqui; ele não podia nos levar mais longe (Moisés não entrou na terra prometida). Surge o novo diretor-presidente e este será agora o grande condutor, que levará os membros da organização mais adiante. $\mathrm{O}$ amor ao antigo 
permanece, como por alguém que morreu. É como respeito, como lembrança, como assassinato. Com o novo, dá-se a introjeção, a adesão, a submissão. Quem escolhe quem, os liderados ou o líder? É recíproco, um escolhe o outro.

Entretanto, as organizações/instituições, também ocupam o lugar dos ideais dos egos dos seus funcionários, seus líderes fazendo a mediação ou tradução dos símbolos organizacionais. As organizações inscrevem no indivíduo a ilusão do sujeito completo, sem o sentimento humano de falta, uma vez que fornecem uma identidade, um lugar social, uma referência. Ela acoberta a castração, a perda do seio, a falta. A organização define comportamentos esperados mediante o relacionamento funcional. São os conjuntos de papéis, os desempenhos de papéis, os comportamentos de papéis, de uma certa visão da teoria dos sistemas.

Ocupando o lugar do ideal do ego, a organização representa a demanda de um grupo de dirigentes. É esta demanda que caracterizará o ideal do ego através do discurso no qual os indivíduos encontrarão sua identificação. É em geral este o processo pelo qual os indivíduos constroem sua condenação ao sucesso em nossas sociedades capitalistas.

É pelo discurso que a submissão acontece. É ele que a todos une sob as razões de bem da empresa, visão do futuro, vestir a camisa. Trata-se de um sistema que se mantém pela referência, isto é, pelo amor, bem como pelo medo de ser punido, ou seja, pelo medo. É também uma forma de angústia que leva a fazer sempre mais.

A introjeção e a adesão vêm como consequiência do indivíduo não desejar o confronto com sua condição humana. A adesão é uma forma de prosseguir na ilusão de ter acobertada a falta ou castração. Subir na hierarquia, obtendo mais e mais poder, faz parte de uma cadeia de submissões contínuas. Ascender ao poder é uma maneira de subjugar e dominar. É evidenciar a aniquilação do outro, acobertando a própria. Trata-se de uma reação em cadeia. Chefes e subordinados fazem parte de uma teia, partilhando o mesmo simbólico. Quem submete os gestores? Os próprios gestores. Estão todos aprisionados na mesma cadeia /armadilha, mesmo que em alguns casos, de ouro, que os ilude com símbolos como promoções, benefícios, privilégio, salários, stock options... (Aguiar, Pereira de, S. e Gobbo Junior, J. A., 2000). 


\section{Organizações Hipermodernas}

Geralmente se fala de ideologia produzida por uma instituição, referindo-se à maneira como os detentores do poder representam a realidade, de forma a mascará-la e ocultá-la. É verdade que tais funções são desempenhadas pela ideologia, mas por si só não explicam de forma alguma a dominação profunda que uma organização hipermoderna, caso da maioria das multinacionais, pode exercer sobre seus participantes. A ideologia não é um sistema perfeitamente coerente e monolítico que tão somente corresponde aos interesses das classes dominantes. Muitos elementos estão presentes na ideologia de uma instituição; esses elementos são resultantes de muitas influências e representam heranças dos diferentes períodos. Uma ideologia só pode ser imposta na medida em que integra ideologias próprias daqueles que quer submeter. $O$ grupo dominante deve oferecer uma interpretação da realidade, coerente, ainda que em termos relativos, com a prática dos membros da instituição, fornecendo uma concepção do mundo conforme suas aspirações.

Nas organizações hipermodernas, a ideologia dominante corresponde à "necessidade de crer" dos membros. É por essa razão que elas podem ser pensadas como locais onde se elabora uma nova forma de religião. Os funcionários participam cada vez mais da ideologia, na medida em que participam de sua elaboração, num amplo processo de autopersuasão. Eles contribuem para sua própria submissão.

A contribuição dos participantes para a produção da ideologia, depende em grande parte de sua integração ideológica. É essencial na ideologia, sua função de reforço da dominação e da exploração. Para tanto, a empresa hipermoderna utiliza pouco a ameaça, centrando-se em dispositivos técnicos e ideológicos sofisticados, que assumem a aparência e os contornos de algo semelhante à religião tradicional. Se a empresa pode substituir a religião para muitos indivíduos é todavia uma questão complexa, pois estamos diante de uma metáfora de religião e não de uma religião propriamente dita. $\mathrm{O}$ vocabulário, porém, dos funcionários das grandes empresas tem muito de religioso. 
Trabalhar numa empresa como a IBM significa aderir a todo um sistema de crenças e valores, significa aderir a uma filosofia, a entregar-se de corpo e alma, com todas as energias, ao trabalho e à vida organizacional. É assim que se dá a dominação por parte da empresa e a alienação por parte dos indivíduos. Todavia, neste jogo, todos são alienados, na medida em que todos participam da ideologia.

Empresas desse tipo, diferentemente de empresas convencionais parecem satisfazer a uma necessidade de crença interna dos indivíduos e de dedicação a um objeto de culto. São empresas que propõem crenças e valores sistematizados, uma moral de ação, tudo levando à adesão psíquica dos funcionários. Note-se que os executivos não escapam a este processo, qualquer que seja seu nível, sendo talvez o seu principal alvo.

Nos manuais da organização ficam consignados esses valores, e é por essa razão que eles podem ser vistos metaforicamente como escrituras "sagradas", concretizando um conjunto de práticas rituais utilizadas pela hierarquia para o funcionamento da organização. À primeira vista, a hierarquia aparece como transcendente aos participantes da empresa, fundando-se sobre uma ética que a faz passível de ser venerada enquanto objeto de culto.

Max Pagès e seus colaboradores entendem que estamos diante de um sistema religioso e não de uma simples metáfora, pelo fato de dispormos de todos os elementos em torno dos quais se articula um sistema desse tipo. A nosso ver, cada um desses elementos é metafórico, podendo no máximo constituírem juntos uma religião laica, uma metáfora de religião. (Pagès, Max; Bonetti, Michel; de Gaulejac, Vincent e Descendre, Daniel, 1998, pgs.74 e 74).

Seriam os seguintes os elementos "religiosos" encontrados em grandes multinacionais hipermodernas: um conjunto de crenças compondo um dogma; escrituras "sagradas" e ritos pondo em prática esse conjunto de crenças; uma organização hierarquizada servida por seus celebrantes; uma massa de fiéis compartilhando a mesma fé, e um deus encarnado pela organização.

$\mathrm{Na}$ realidade, há um conjunto de elementos diversos que "sacralizam" o mundo profano da produção capitalista. Para alguns, tais elementos constituem uma substituição das religiões tradicionais num momento em que elas atravessam uma crise profunda. Para 
outros, a ideologia empresarial representa muito mais um simulacro da religião tradicional, principalmente de seus aspectos disfuncionais, tais como cegueira e fanatismo.

Os membros das empresas hipermodernas reconhecem-se nelas. Isto ocorre, em grande medida, porque elas oferecem-lhes, além das satisfações materiais, satisfações ideológicas e também espirituais. Dessa forma, eles se identificam com a sua força. Tais satisfações fazem parte do sistema de valores e crenças que a organização propõe. Trata-se de um quadro de referências coerente e ambicioso.

Os participantes vêem esse quadro de referências como conceitos, idéias e filosofias básicas, ou como uma filosofia coerente com necessidades no plano pessoal. Os princípios são relacionados com a felicidade em fazer parte da organização. A filosofia global leva à adesão pelo simples fato de existir.

O sistema oferece uma visão global do mundo, uma forma de interpretá-lo, que, seja qual for sua natureza, fornece a base de modelos de comportamento. O êxtase e a fascinação são inevitáveis diante da descoberta de que tudo estava previsto, organizado e estruturado. Não há a necessidade de elaborar normas e comportamentos próprios. O sistema lhes fornece toda a segurança. Estamos diante de uma característica dos sistemas totalitários.

A instauração de um sistema de valores torna prolongada a codificação das práticas no plano das representações sociais. Sua função principal é a legitimação do sistema de regras. Ele possui a chave para a elaboração das representações do que foi vivido, fornecendo os princípios fundamentais de acordo com os quais as pessoas orientam suas ações. As comunicações, as trocas e as relações interpessoais também se orientam pelo sistema de valores.

Se um discurso proveniente de um participante da organização é pertinente ou não, é matéria de avaliação a partir desse sistema de referências. É uma linguagem muito específica da organização, que permite ao mesmo tempo que serve para seu reconhecimento, para o reforço de sua coesão e para modelar a conduta de seus participantes. 
Para que alguém seja compreendido no interior da organização, é preciso que adote essa linguagem. É assim que se situa em relação às normas por ela enunciadas. O discurso que foge a ela não será entendido. Está fora do campo de representações coletivas delimitadas. O discurso não seria combatido, nem mesmo seria visto como ameaçador. Seria apenas visto como irrelevante e incongruente.

O discurso organizacional hipermoderno pode ser considerado como discurso fechado no sentido marcuseano (Marcuse, H., 1973, apud Max Pagès e outros, 1979, pg. 78). Em tal sentido, um discurso fechado é aquele que possui em si suas próprias contradições e que se fecha a qualquer outro modo de expressão.

Trata-se de uma moral de empresa. Se os indivíduos aderem a ela com tanto entusiasmo, é porque encontram nela um conjunto de princípios em que podem acreditar. Trata-se da busca de um sentido para suas existências. Se o sistema é forte é porque ele se adapta à realidade vivida no cotidiano.

As religiões da esfera do sagrado, em um número significativo, enfrentam grandes dificuldades nos dias que correm, devido à sua incapacidade de traduzir o cotidiano das sociedades contemporâneas para o plano do espírito. São religiões coerentes com as sociedades agrárias, nas quais a dominação dos homens pela natureza é considerável. É dela que eles recebem o essencial para a sua sobrevivência. A onipotência de um deus parece ser então a única explicação satisfatória de sua contingência extrema. O objeto da religião do sagrado é conseguir a indulgência de um ser tão poderoso como este.

Quando a humanidade transforma significativamente suas condições naturais e quando o domínio do meio ambiente a partir do conhecimento é o grande objetivo, toda a energia humana é direcionada para a redução da contingência. Para um grande número de pessoas, o deus todo poderoso é ransferido para os processos técnicos e para as estruturas sociais que os contém.

\section{Organização e Religião: Concluindo}

Assim, a moral tradicional associa-se à prática religiosa convencional. $\mathrm{O}$ respeito $\mathrm{e}$ a submissão às condições naturais e à ordem estabelecida contradiz a experiência da 
sociedade industrial, fundamentada na transformação dessas condições e na mudança acelerada de técnicas e métodos. $\mathrm{O}$ indivíduo adere àquilo que percebe como um sistema de valores coerente com sua própria experiência, na medida que a torna inteligível e a valoriza. Os empregados de uma empresa multinacional buscam saber se o que fazem contribui para a transformação da organização e do mundo, do qual participam efetivamente e para o qual sabem que podem colaborar cada vez mais. A religião laica, que é a organização hipermoderna, consegue persuadir e convencer que do mais modesto trabalho na empresa depende até mesmo o futuro da humanidade, no que não há muita espiritualidade.

Não há uma passagem da religião da esfera do sagrado para a religião laica, da empresa. Elas convivem. Todavia, a segunda pode tomar o lugar de vastas áreas da primeira, mesmo que muitas religiões do tipo tradicional, com matrizes nessas, surjam. É o caso do pentecostalismo, com milhares de adeptos, embora essas religiões agreguem mais pessoas de classe baixa e classe média baixa. Talvez essas pessoas não vejam relação tão direta entre sua prática social e o sistema de valores das empresas.

É preciso considerar também que a organização como religião laica era extremamente forte nos anos setenta, principalmente nos países desenvolvidos, tendo enfraquecido posteriormente com a perda da perspectiva de continuidade de emprego e de possibilidade de carreira interna na empresa. Nesse momento, a organização como religião laica passa a concorrer com a carreira interorganizacional como medida de sucesso. Todavia, a religião laica da organização enfraquece, mas não desaparece.

Muitos elementos da religião da esfera do sagrado são atualizados e reinterpretados na religião laica, de modo que muitos de seus mecanismos continuam a funcionar dessa forma. Assim, o respeito ao indivíduo, a valorização do esforço e do sacrifício, a perseverança e a integridade, valores essenciais da ideologia humanista cristã, são usados para mascarar as condições reais de exploração.

Valores modernos são acrescentados aos valores cristãos tradicionais. São valores como mudança, progresso técnico, eficácia e sucesso individual. É uma nova cultura que se forma mediante a integração de valores antigos e novos, formando um sistema novo cujas 
bases são todavia contraditórias com a moral tradicional associada ao cristianismo e talvez a outras religiões tradicionais.

$\mathrm{O}$ que se mantém, e que é comum às religiões tradicionais e à religião da empresa é o mecanismo que situa o homem em uma relação de identificação / submissão. O poder divino é aqui metaforicamente o poder da organização e serão sempre respeitadas as regras instituídas por esse poder para nele participar e receber seus benefícios.

Redescobre-se igualmente certa mística do chefe, do responsável, daquele que melhor encarna os princípios do sistema, que garante a sua realização. É aquele que se consagra totalmente à organização, que verá seus esforços coroados de êxito, recompensados por uma promoção na hierarquia. Simbolicamente, a valorização dos responsáveis é um elemento central do sistema de valores, mesmo admitindo-se que o essencial do poder escape aos responsáveis hierárquicos.

Dessa forma, chegamos ao credo, um conjunto de valores que pode ser resumido da seguinte maneira: progresso técnico e mudança; auto-superação, esforço e sacrifício; respeito e consideração para com o indivíduo; espírito de competição, sucesso individual, individualismo; integridade, honestidade exigida de todos e em particular dos responsáveis; responsabilidade para com o mundo, contribuição para a melhoria da sociedade; busca de perfeição; qualidade dos serviços fornecidos e dos produtos acabados; igualdade de oportunidades de promoção; ausência de favoritismo; liberdade de expressão, possibilidade de exprimir a todo momento suas dificuldades, seus problemas e suas aspirações; contribuição para a felicidade dos indivíduos; sentimento de plenitude pelo trabalho e recompensa dos esforços dedicados à empresa.

São preceitos oficiais e declarações de fé que empregados de multinacionais hipermodernas fazem. Os indivíduos colaboram para a formação desse sistema de valores, colocando-os em seu discurso cotidiano. Alguns desses valores são claramente tradicionais como a noção de sacrifício, o respeito ao indivíduo e a integridade. Outros elementos são mais contraditórios como o espírito de competição, o individualismo e a eficácia, mas combinam-se com os primeiros. O resultado da combinação é uma moral de ação, que implica até mesmo em regras práticas de funcionamento. $\mathrm{O}$ sistema tem sua credibilidade 
fundamentada no fato desses valores serem postos em prática. É principalmente na política de recursos humanos que isto se dá.

O que uma empresa hipermoderna faz é propor a seus funcionários que dêem sua contribuição para a transformação do mundo, para o progresso técnico, para a melhoria das comunicações, da educação, para o tratamento das doenças, isto é, para assumir uma posição proativa na vida individual e social.

A idéia é que fazendo isto, as pessoas criem condições para sua realização, assumam responsabilidades e se exprimam com liberdade num ambiente de trabalho agradável, no qual haja respeito pelos indivíduos. O que não fala o discurso, é da prisão psíquica em que os indivíduos se enveredam, colocando a organização no local de seu ideal do ego.

O entusiasmo nessas condições pode ser facilmente provocado, já que elas oferecem uma razão de ser. A qualidade da empresa e de seus produtos soma-se a isto. É assim que se provoca uma verdadeira fé. A empresa é vista como o único lugar onde isto pode ser encontrado. Para muitos, ela não é passível de crítica.

Todas as características da empresa e todos os elementos da experiência individual no contexto da organização hipermoderna tendem a ser valorizados e a serem considerados positivos, à partir da adesão aos princípios básicos e às crenças compartilhadas amplamente pelo conjunto do pessoal.

Funções e condições de trabalho que apresentam condições inerentemente restritivas são atenuadas por essa "fé na empresa". O próprio sacrifício da vida familiar ou de outros prazeres que o trabalho torna difíceis pode ser anulado pela "fé". Ela é ainda reforçada por estar escrita em manuais, donde a metáfora "textos sagrados".

Esses textos compõem uma espécie de "bíblia" que pode ser consultada a qualquer momento. São três os tipos de "textos sagrados": as crenças básicas, os princípios de funcionamento e os manuais de aplicação. 
As primeiras exprimem os fundamentos da ideologia oficial. Já os segundos, apresentam alguma analogia com os "mandamentos" do judaísmo e do cristianismo, pois, como o nome indica, objetivam guiar a ação dos participantes da organização.

As crenças e os princípios referem-se à totalidade da organização, definindo a ética da empresa. Os manuais de aplicação são muito mais específicos, dizendo respeito a cada função e reunindo regras que cada responsável hierárquico deve respeitar. Embora se apresentem como instrumentos de gestão, são marcados pela ideologia oficial da qual permitem a prática. Podem ser considerados como "práticas ideológicas".

Podem-se distinguir duas práticas básicas. A primeira é o respeito pelas pessoas ( a consideração pelos empregados, o serviço aos clientes). A segunda é a excelência ( do indivíduo, da organização).

Tais valores circulam entre três pólos e regulam suas relações: o indivíduo, a organização e o mundo ( os clientes e a humanidade).

A excelência da organização é assegurada pela excelência dos indivíduos que por esta razão a respeitam. Em termos inversos, o indivíduo sendo respeitado, almeja sua excelência e a organização. Sua eficácia e seu poder permitem que o indivíduo seja respeitado. É igual a relação com os clientes e a humanidade, isto é, o mundo. Reproduz-se uma vez mais a ideologia da harmonia administrativa. É a visão de um universo harmonioso, em que os valores eliminam o conflito. A organização, ao mesmo tempo, aparece como um novo valor, regulando as relações entre indivíduos e mundo e garantindo a manutenção da estabilidade do sistema.

O que transparece por traz dessas crenças é o modo ideológico de domínio: uma imagem moralista e humanista de respeito ao indivíduo e prestação de serviço e, da mesma forma, uma imagem de superioridade que disfarça o poder. Poder e generosidade são atributos divinos, que colocam a organização como sujeito da história, princípio de tudo, garantindo assim sua deificação ou "sacralização", para ser menos exagerado na metáfora. Uma organização pode desaparecer por maior e mais poderosa que seja. Isto não pode ocorrer com um deus. 
É o status de instância moral que a organização adquire, status de consciência transcendente ao mercado. Os princípios deste último são assim esvaziados. Traduzida esta moral em termos capitalistas, encontraremos os objetivos reais das organizações hipermodernas.

Assim, tornar-se a empresa mais poderosa do mundo, controlar inteiramente o mercado, segurar completamente o cliente, obter o lucro máximo, são alguns dos verdadeiros objetivos de diversas multinacionais, como era de se esperar. Tais objetivos são atingidos por intermédio da relação moral que une a organização a seus funcionários, desde executivos até operários.

Essa relação moral implica em um vago sentimento de culpa que paira difusamente sobre os empregados, quando eles não conseguem honrar a confiança de que são investidos. Tudo se passa de modo que o empregado seja sempre um "devedor de favores", de uma organização que o quer e que o respeita. Trata-se de uma "dívida moral" que, de fato, oculta a subordinação e que jamais pode ser honrada (Pagès, Max; Bonetti, Michel; De Gaulejac, Vincent; Descendre, Daniel, 1981, pgs. 76 a 82).

A religião laica da empresa é paralela ao enfraquecimento das religiões tradicionais. Um número menor de judeus e católicos segue de forma ortodoxa suas religiões e ainda que o protestantismo ( o luteranismo e o calvinismo) fosse desde a sua origem um fenômeno em forte sintonia com o processo moderno de secularização da sociedade ocidental, sendo muito mais aberto para as mudanças liberalizantes, como o movimento das mulheres, o aborto, o capitalismo, etc... , foi também a "religião" que mais se enfraqueceu na modernidade, dentro do universo cristão europeu. A tese de Jean-Paul Willaine "é que exatamente essa sintonia que gera a precariedade. O protestantismo histórico apresentou sempre uma preferência pelo discurso racional, pela prédica em detrimento do ritual".

"Essa postura racionalista faz com que esse protestantismo esteja sempre mais aberto para as variações das concepções filosóficas em ação em uma determinada época e, se teve sucesso nos séculos XVI e XVII, foi exatamente porque naquela época a teologia era uma referência fundamental dentro do panorama filosófico europeu. Na medida em que a teologia "decaiu", esse protestantismo também perdeu seu espaço". 
"O ritual, o emocional parecem durar mais no tempo e estão mais "protegidos" do desgaste das concepções filosóficas. Na sociedade moderna essa hiperadaptação significou a perda da visibilidade na lógica psicossocial. Sua ética contextual se dissolveu no mundo secularizado. É interessante perceber que o retorno ao protestantismo se deu exatamente por meio de sua veia emocional, isto é, o pentecostalismo." (Willaime, Jean_Paul, apud Luiz Felipe Pondé, 2001, pg. 30)

Tais considerações não são suficientes para se afirmar que a religião laica da empresa substituiu as religiões tradicionais, porém mostra a importância do rito e do emocional, numa época em que o catolicismo simplificou consideravelmente os seus ritos. Numa fase posterior, práticas religiosas semelhantes a do pentecostalismo, além do uso da media, serão vistas em cerimônias católicas.

A religião laica, sem deus, da organização, é rica no uso que faz da dimensão emocional, no jogo que engendra entre promessa de realização e sofrimento, e no uso de ritos diversos, de iniciação, passagem e afastamento.

Que homem é produzido e é produtor pelas e das organizações hipermodernas? Como ele nasce? Em primeiro lugar, parece que surge do crescimento do narcisismo estudado por sociólogos, filósofos e psicanalistas norte-americanos e franceses.

Entre os sociólogos e filósofos podemos citar Richard Sennett, Christopher Lasch e Gilles Lipovetzsky. Entre os psicanalistas estão André Green, Otto Kernberg, Jean Bergeret, Didier Anzieu e Bela Grunberger. Alguns consideram que estamos assistindo a algo que consideram uma mutação antropológica.

Estaríamos assistindo ao "surgimento" de um perfil inédito de indivíduo nos seus relacionamentos com si próprio e seu corpo, com o outro, o mundo e o tempo, no momento no qual o capitalismo autoritário cede o passo a um capitalismo hedonista e permissivo (Lipovetzsky, pg. 53, apud Aubert, N. et De Gaulejac, V., 1991, pg.154).

Trata-se de um novo indivíduo voltado para uma busca sem limites de realizações pessoais tanto ao nível do corpo quanto da expressão de si próprio. É um Narciso dos tempos modernos, cujo surgimento Sennett situa após a Segunda Guerra Mundial. 
Até sua aparição, as pessoas eram guiadas pelos grandes sistemas de sentido, principalmente religiosos, mas também políticos. Esses sistemas propunham certas metáforas às quais os indivíduos aderiam. Eram elas que estabeleciam limites para o comportamento humano. Todavia, quando começaram a provocar consequiências em contradição com seu discurso humanista, começaram a perder força.

Acompanha tal fenômeno o desinteresse crescente pelas grandes questões. É como se uma onda de apatia assolasse a sociedade. Só a esfera privada parece fugir um pouco disto. Dessa forma, a questão de onde passar as férias é fundamental para a classe média na maioria dos países industrializados; cuidar da saúde, preservar a situação material, livrar-se de complexos, são também questões muito importantes. Viver sem objetivos transcendentes torna-se aparentemente possível.

É uma sociedade do vazio, que se procura preencher através dos esportes radicais, das operações plásticas, da moda, dos relacionamentos sociais ligeiros. A empresa é, para a maioria, o local social central, o lugar onde se busca a identidade. É ali que os indivíduos buscam sentido e realização sob o movimento da empresa com seu discurso sedutor, que os atrai e galvaniza suas energias a serviço de seus objetivos econômicos.

Dessa forma, o homem da organização busca na empresa uma resposta ao vazio, perseguindo e projetando nela suas necessidades de crença e de realização. Isto se dá ao mesmo tempo em que a empresa o modela a partir de seus próprios projetos, crenças e idéias. Em suma, a empresa o modela em termos de seu imaginário. $\mathrm{O}$ resultado desses dois movimentos é a religião laica. (Vide Aubert, Nicole e De Gaulejac, V., 1991, pgs. 154 a 164)

Não poderia deixar de ser dessa forma.

"Enquanto sistema social relativamente integrado e autônomo em torno das relações de trabalho, as empresas, que poderíamos comparar a mini-sociedades globais, não podem evitar basear suas interações humanas sobre regulações culturais. O universo de representações articuladas em mitos, valores e símbolos intervém profundamente sobre a articulação das relações entre agentes, assim como sobre a definição mais institucional das regras e estruturas de organização e de trabalho" (Sainsaulieu, Renaud, 1988, pg.445) 


\section{Bibliografia}

1. Aguiar, Pereira de, Silvana e Gobbo Junior, José Alcides, Moisés e o Monoteísmo: Introjeção, Adesão, Fascínio e Sedução, Teoria das Organizações, mimeo,2000.

2. Aubert, Nicole et De Gaulejac, Vincent, Le Côut de l'Excellence, Paris, Seuil,1991.

3. Bertero, Carlos Osmar \& Keinert, Tânia "A evolução da análise organizational no Brasil (1961-1993)", Revista de Administração de Empresas, vol. 34, n 3, p. 81-90, 1994

4. Burrell, M. \& Morgan, G. Sociological paradigms and organisational analysis elements of the sociology of corporate life. London: Heinemann, 1979.

5. Chanlat, Jean-Françoise $O$ Indivíduo na Organização: Dimensões Esquecidas. Vol. I São Paulo: Atlas, 1994.

6. Clegg, S.; Hardy, C.; Nord, W. R. (Eds) CALDAS, M.; FACHIN, R. \& FISCHER, T. (Trad.) Handbook de Estudos Organizacionais. São Paulo: Atlas, 1999.

7. Enriquez, Eugene, Da Horda ao Estado. Psicanálise do Vínculo Social, Rio de Janeiro, Jorge Zahar Editor, 1990.

8. Freud, Sigmund, L'Avenir d'une Illusion, Paris, PUF, 1971.

9. Freud, Sigmund, Moisés e o Moneteísmo, E.S.B., vol. XXIII, São Paulo, Imago, 1975.

10. Freud, Sigmund, Psychologie de Foules et Analyse du Moi, Essais de Psychanalise, Paris, Payot, 1981. 
11. Freud, Sigmund, Totem e Tabu, Edição Standard Brasileira, São Paulo, das Obras Completas de Sigmund Freud (E.S.B.), vol.XIII, Imago,1974.

12. Hatch, Mary Jo Organization Theory. Oxford: Oxford University Press, 1997.

13. Lipovetzski, G., L'Ere du Vide, Paris, Gallimard, 1983.

14. Marcuse, H., A Ideologia da Sociedade Industrial, Rio de Janeiro, Zahar, 1973.

15. Pagès, Max; Bonetti, Michel; De Gaulejac, Vincent e Descendre, Daniel, O Poder das Organizações. A Dominação das Multinacionais sobre os Indivíduos, São Paulo, Atlas, 1986.

16. Prestes Motta, Fernando Cláudio \& Freitas, Maria Ester Vida Psíquica e Organização. Rio de Janeiro: FGV, 2000

17. Reed. Michel "Teorização organizacional: um campo historicamente contestado". In: ClEGG, S.; HARDY, C.; NORD, W. R.; CALDAS, M.; FACHIN, R. \& FISCHER, T. (Eds.) Handbook de Estudos Organizacionais. São Paulo: Atlas, 1999.

18. Sainsaulieu, Renaud, L'Identité au Travail, Paris, Presses de la Fondation Nationale des Sciences Politiques, Paris, 1988.

19. Schikmann, Rosane; Coimbra, Rosangela e de Battisti, Patrícia, Organização como Religião Leiga, Teoria das Organizações, mimeo, 2000.

20. Vergara, Sylvia "Análise organizacional no Brasil: em busca da independência intelectual", Colóquio de Estratégia e Organização. Zacatecas, 2000

21. Willaime, Jean-Paul, em Luiz Felipe Ponde, O Enfraquecimento do Protestantismo, Folha de São Paulo, MAIS, 21 de janeiro de 2001. 
